\title{
ÁAirman
}

Jurnal Teknik dan Keselamatan Transportasi

\section{Manajemen Perubahan dalam Organisasi AMTO 147 D-13}

The Transformation Management in Organization

\author{
Mulyadi Nur \\ dadiatkp82@gmail.com
}

Politeknik Penerbangan Makassar

\begin{abstract}
ABSTRAK
Organisasi perlu memikirkan keberadaannya, organisasi tidak akan mundur dari perubahan dan perubahan aktivitas. Isu-isu terkait kegiatan manajemen perubahan, telah muncul di media, pidato organisasi perkuliahan orang, dan diskusi akademik tentang organisasi. Kami telah menyaksikan berbagai perubahan yang terjadi, apakah perubahan kurang signifikan, dan perubahan besar yang berdampak dalam sejarah organisasi dan individu dalam organisasi. Penelitian ini betujuan untuk menganalisa sasaran-sasaran perubahan yang sifatnya organisasional. Hasil penelitian ini menunjukkan bahwa tidak semua orang suka atau siap terhadap perubahan dalam organisasi, namun demikian perubahan tersebut mau tidak mau harus dihadapi.
\end{abstract}

Kata kunci: manajemen perubahan; organisasi

\section{ABSTRACT}

Organizations need to think about their existence, they won't back down from changes and changes in activity. Issues related to change management activities, have appeared in the media, speeches of organizations lectures people, and academic discussions about the organization. We have witnessed a variety of changes that occur, whether the changes are less significant, and major changes that have an impact in the history of organizations and individuals in the organization. This research aims to analyze the goals of change that are organizational in nature. The results of this study show that not everyone likes or is ready for changes in the organization, but nevertheless those changes inevitably have to be faced.

Keywords: change management; organization

\section{PENDAHULUAN}

Di era globalisasi saat ini, perubahan tidak dapat dielakkan dalam kehidupan sehari-hari. Perubahan adalah suatu hal yang pasti, dimulai dari ruang lingkup organisasi pemerintahan hingga ranah bisnis yg lebih awal sadar akan pentingnya perubahan yang berdampak dalam peningkatan kualitas produksi yg dihasilkan. Sudah berbagai macam cara diupayakan guna mencari solusi dari timbulnya permasalah yang ada dari adanya perubahan.

Dalam hal ini, Heraclitus yang merupakan seorang filsuf Yunani kuno pernah menyampaikan bahwa tidak ada yang lebih permanen di dunia ini daripada perubahan. Karena perubahan akan selalu terjadi di dunia ini, meliputi segala aspek di dalamnya seperti 
kehidupan, baik pada tingkat individulisme maupun organisasional.

Selain perubahan yang konstan dalam setiap aspek kehidupan, menarik untuk dicermati bahwa perubahan di satu aspek pasti memiliki dampak berupa input maupun output langsung atau tidak langsung atas aspek kehidupa. Bisa dikatakan bahwa, korelasinya mungkin tidak langsung terlihat karena perubahan adalah variabel dependen dari perubahan di domain lain, tetapi korelasi serta interdependensi aktual selalu ada.

Perubahan adalah hal yang pasti dalam keberlangsungan dalam organisasi. Bagi pemerintah seperti kita ketahui betapa pentingnya perubahan untuk meningkatkan kualitas produk yang dihasilkan. Untuk mencapai solusi karena perubahan organisasi, organisasi telah menerapkan banyak program penjangkauan.

\section{A. Identifikasi Masalah}

Karena perubahan selalu terjadi secara berkesinambungan serta teratur, para pemimpin pemerintahan diharapkan lebih peka kepada tanda-tanda perubahan yang sedangterjadi di luar organisasi serta memiliki ekspektasi maupun pandangan tentang dampak dari perubahan tersebut, oleh karna itu perlu juga seorang pimpinan dalam organisasi memiliki kemampuan (skill) untuk membuat sebuah perubahan demi terciptanya kemajuan dalam sebuah organisasi.

Selalu ada kontradiksi dalam perubahan, serta beberapa akan membencinya dan yang lain tidak akan siap, dan walaupun demikian perubahan ini tidak dapat dihindari, tetapi harus menemukan formula khusus untuk mengatasinya yang dapat memengaruhi proses perubahan yang menguntungkan organisasi.

\section{B. Rumusan Masalah}

Hanya sedikit orang-orang yang menyukai perubahan, tetapi kenyataan itu tidak dapat dihindarkan. Oleh karena itu, manajemen perubahan diperlukan untuk memastikan bahwa prosesi serta dampak dari perubahan ini mengacu atas hasil yang positif.

Membuat perubahan dapat menyebabkan sejumlah masalah. Masalah yang paling umum serta jelas adalah "kemampuan untuk menolak perubahan". Adapaun penjelasan yang umumnya dipahami oleh kalangan manajerial adalah resistensi terhadap perubahan. Resistensi terhadap perubahan tidak selalu negatif. Karena penolakan, itu tidak dapat diubah dengan sengaja. Resistensi terhadap perubahan tidak selalu muncul secara standar.

Penolakan jelas terjadi (clear) dan langsung. misalnya atau secara implisit (non eksplisit) secara progresif, misalnya, loyalitas terhadap organisasi serta institusi menurun, motivasi kerja yang melemah, kurangnya ketelitian dalam lingkup kerja meningkat, absensi meningkat dan lain sebagainya.

Masalah penolakan terhadap perubahan terbagi atas dua, yaitu penolakan individu serta penolakan organisasional. Penolakan individu umumnya disebabkan oleh:
a. Kebiasaan
b. Perasaan aman
c. Faktor-faktor ekonomi
d. Takut akan hal yang tidak diketahui
e. Pengakuan

Sementara penolakan secara organisasional disebabkan oleh:
1. Inersia struktual atau penolakan terstruktural
2. Fokus atas pentingnya dampak perubahan
3. Inersia dikalangan pekerja
4. Ancaman terhadap profesionalisme
5. Ancaman terhadap kekuatan yang mapan
6. Ancaman terhadap alokasi sumber daya

\section{Manajemen Perubahan dan Penyebab Perubahan}

Merujuk pada KBBI, perubahan adalah hal (keadaa) berubah; peralihan; pertukaran. Dalam suatu organisasi, manajemen perubahan adalah tekanan yang disebabkan oleh perubahan itu sendiri dan tanggapan atau tindakan yang direncanakan atau tindakan situasional terhadap tekanan tersebut. Perubahan merupakan respon yang sudah terencana atau tidak terencana terhadap tekanan yang ada. Upaya untuk mengelola hasil perubahan dalam sebuah organisasi adalah manajemen perubahan. Perubahan membantu organisasi bertahan. Manajemen dapat melihat bahwa organisasi tetap sama dan tidak bertahan lama. Perubahan memiliki manfaat untuk memastikan keberlangsungan hidup suatu organisasi. Perubahan dapat terjadi karena alasan internal atau eksternal organisasi.

Di dalam hal perubahan dan perkembangan, itu pasti terjadi dan semua orang tidak terkecuali di aspek organisasi. Namun, bagi banyak individu dan organisasi yang menyukai perubahan, perubahan adalah keniscayaan, tetapi 
harus dihadapi dengan berani. Secara garis besar faktor perubahan dalam suatu organisasi dapat diakibatkan karena dua faktor yaitu:

1. Faktor Internal; aktor-faktor ini adalah semua faktor yang ada dan terdapat didalam struktur organisasional yang dapat mempengaruhi jalannya organisasi dan organisasi afiliasinya.

2. Faktor Eksternal; termasuk dalam keseluruhan faktor yang ada dan terdapat di luar organisasi dan dapat mempengaruhi organisasi dan kegiatannya. Faktor-faktor ini termasuk politik, hukum, budaya, teknologi, sumber daya alam, demografi, dan sebagainya.

Perubahan tersebut mempengaruhi sejumlah perubahan pada jaringan, seperti perubahan sifat jaringan. Untuk mengatasi masalah ini, organisasi perlu menetapkan dan menyesuaikan langkah-langkah dan kebijakan sehingga etos organisasi lama tidak hilang atau diganti. Apabila terjadi perubahan struktural organisasi, maka struktural organisasi harus disusun dan berpedoman atas prinsip-prinsip yang telah ditetapkan dengan tujuan untuk memberikan gambaran tentang organisasi.

Perubahan organisasi, pada umumnya ditemukan sejumlah hambatan dalam proses perubahan. Hambatan tersebut biasanya berasal dari faktor eksternal atau eksternal. Perubahanperubahan ini tetap dinamis daripada statis, terlepas dari evolusi, teknologi, dan peningkatan kesadaran publik akan layanan berkualitas di sektor utilitas. Tidak ada perubahan yang dapat dilakukan tanpa kerjasama dari pihak-pihak terkait. Williams et al. (2002) berpendapat bahwa teori kerjasama menjelaskan mengapa orang ingin bekerja sama dan bagaimana mencapai kerjasama. Ada banyak alasan orang ingin bekerja sama antara lain:

- Adanya motivasi dalam memperoleh penghargaan atau bisa disebabkan oleh kekuatiran akan mendapatkan hukuman.

- Adanya motivasi untuk setia terhadap profesi, pekerjaan atau perusahaan.

- Adanya motivasi moralitas, karena dengan bekerja sama dapat diterima secara moral.

- Adanya motivasi menerapkan keahlian.

- Adanya motivasi karena sesuai dengan sikap hidup yang dipahami.

- Adanya motivasi kepatuhan terhadap kekuasaan yang berkuasa.
Setiap bisnis memiliki tujuan tertentu yang dapat dilihat melalui beberapa tahapan transformasi sebagai sebuah organisasi. Untuk mengelola perubahan, Manajemen perlu mengetahui tahapan perubahan. Manajemen perubahan terbagi menjadi empat tahapan:

- Tahap 1, adalah mendefinisikan perubahan dan seseorang dapat mengetahui perubahan apa yang dibuat serta memahami apa yang sedang. Pada momen ini, kelompok atau individu dapat mengenali kebutuhan akan perubahan dan menentukan jenis perubahan.

- Tahap 2, adalah tahap perencanaan perubahan. Pada tahap ini Pada tahap ini, diagnosis situasi teknis, pilihan strategi umum dan opsi harus dianalisis. Dalam proses ini, faktor pendukung harus diperhatikan agar perubahan yang tepat dapat terjadi.

- Tahap 3, adalah tahap perubahan yang mengarah ke proses pencairan, pemupukan, dan pembekuan yang dimaksudkan. Mengubahnya dapat menyebabkan masalah. Untuk itu perlu dilakukan monitoring perubahan.

- Tahap 4, adalah fase evaluasi dan umpan balik. Menilai membutuhkan data, mengumpulkan dan mengevaluasi data pada saat ini. Hasil evaluasi ini dapat kembali ke langkah 1 dan mempengaruhi perubahan yang diperlukan.

\section{E. Tujuan Penelitian}

Ketika menganalisis tujuan perubahan organisasi, seseorang harus selalu memperhatikan hubungan antara tujuan yang dicapai dan tujuan yang dicapai, kecuali jika tujuan spesifik berubah. Bahkan, bukan tidak mungkin untuk berpikir bahwa tujuan umum organisasi dan komponen khusus dari tujuan tersebut harus berubah. Tujuan dari perubahan tersebut adalah untuk:

\section{a. Perubahan Atas Struktural Organisasi}

Salah satu cara mencapai tujuan perubahan organisasi adalah menerapkan struktural organisasi. Perubahan struktural organisasi adalah sebagai berikut:

1) Beberapa aspek perumusan atau penetapan tujuan.

2) Memodifikasi tugas yang akan dilakukan. Misalnya, misi militer yang berlangsung dengan gaya tertentu dalam suasana damai harus berubah jika negara sedang berperang. 
3) Perubahan konstruksi, mengacu pada sifat dan jenis tugas pokok, dan kegiatan operasional.

4) Perubahan beban kerja yang dilakukan di seluruh organisasi atau sebagai bagian tertentu dari organisasi.

b. Perubahan Prosedural Kerja

Perubahan di aspek prosedural dapat terjadi dengan atau tanpa perubahan dalam struktural organisasi. Perubahan alur kerja terjadi secara global dan bahkan dapat mencakup seluruh proses manajemen dan dapat terjadi secara bertahap. Dengan kata lain, ini hanya mencakup sebagian dari proses manajemen. Ade Fauji (2009) berpendapat bahwa, perubahan prosedural kerja meliputi :

1) Perubahan alur kerja penelitian dalam konteks analisis dan pengembangan kebijakan. Dalam konteks analisis pembuatan kebijakan, organisasi modern berusaha untuk melakukan kegiatan penelitian dan mengumpulkan informasi lainnya.

2) Mengubah alur kerja untuk penetapan kebijakan. Menjelaskan gaya manajemen dan kepemimpinan pemimpin organisasi. Dengan kata lain, ketika para pemimpin mengadopsi manajemen terbuka dan partisipatif, mereka mengundang orang-orang percaya untuk mengambil peran aktif dalam pembuatan kebijakan.

3) Perubahan prosedural bisnis dalam proses pengambilan keputusan. Seperti proses pembuatan kebijakan, proses pengambilan keputusan terkait dengan manajemen dan gaya kepemimpinan pemimpin organisasi. Menetapkan secara tegas dan jelas sifat dan bentuk partisipasi berbagai pihak dalam pengambilan keputusan, termasuk perubahan yang dianggap perlu untuk meningkatkan efisiensi dan efektivitas operasional pada tingkat individu dan organisasi.

4) Mengubah proses perencanaan. Ini melibatkan kepekaan dan daya tanggap terhadap perubahan yang terjadi di berbagai aspek di luar organisasi yang mempengaruhi berfungsinya fungsinya. Perubahan proses kerja dalam memobilisasi retribusi. Ubah alur kerja saat melakukan tugas operasional. Hal ini terkait dengan kebiasaan, praktik kerja dan operasional yang biasa dilakukan oleh operator dan tidak dapat diubah dengan mudah. Masalah sering berubah dari masalah teknis menjadi masalah sikap.

5) Mengubah prosedural kerja dari sudut pandang pemantauan kinerja. Pengawasan adalah fungsi manajemen yang sangat penting yang meningkatkan efisiensi, efektivitas dan produktivitas operasi. Singkatnya, pemantauan memainkan peran yang sangat penting dalam menghilangkan atau meminimalkan pemborosan dan penyimpangan dalam rencana yang telah ditentukan. Misalnya, dapat meningkatkan efisiensi organisasi dengan meningkatkan efisiensi pemantauan bersama dengan data operasional IT dan upaya pengumpulan data.

c. Perubahan Dalam Hubungan Kerja sama

Kerjasama yang baik dalam semua pihak dalam organisasi merupakan suatu keharusan. Oleh karena itu, suasana partisipasi yang demokratis harus dikembangkan dan dipelihara dalam organisasi. Namun, jika sebuah organisasi berada di bawah tekanan atau diatur oleh kekuatan yang berlebihan, ia berpotensi memiliki dampak negatif dan organisasi semacam itu tidak akan mencapai tujuannya. Oleh karena itu, perlu untuk fokus pada hubungan kerja. Kolaborasi adalah segala bentuk interaksi pribadi antar anggota suatu organisasi yang terjadi dalam rangka pelaksanaan tugas baik secara vertikal maupun horizontal. Dibawah ini adalah halhal yang perlu mendapat perhatian dalam hal perubahan dalam hubungan kerja antar personal:

1. Loyalitas kelembagaan. Yang perlu ditumbuh kembangkan dalam organisasi adalah bukan tentang orang-orang tertentu yang perlu dikembangkan oleh sebuah organisasi, tetapi tentang loyalitas para anggotanya terhadap organisasi.

2. Kebijakan tentang sifat hubungan kerja hendaknya dinyatakan secara tertulis. Pentingnya kebijakan ketenagakerjaan tertulis tidak hanya dilihat dalam 
konteks kesinambungan, tetapi tidak dapat dengan mudah dimodifikasi agar sesuai dengan preferensi manajemen orang-orang tertentu.

\section{METODE}

Paradigma penelitian ini adalah konstruktivisme sosial dengan desain penelitian deskriptif kualitatif dan strategi studi kasus. Data yang dikumpulkan melalui teknik wawancara langsung, observasi, dan penelaahan terhadap berbagai dokumen terkait. Transkrip wawancara diolah melalui tahap-tahap editing, reduksi, koding, kategorisasi, dan interpretasi.

\section{HASIL DAN PEMBAHASAN}

Perubahan ini mempengaruhi organisasi dan pemangku kepentingannya. Perubahan dapat direaksikan secara positif atau negatif, tergantung dari jenis dan luasnya perubahan itu sendiri. Memberikan dukungan dalam bentuk negatif atau negatif jika menentukan bahwa telah terjadi perubahan yang merugikan manajemen atau anggota organisasi. Di sisi lain, ketika terjadi perubahan inovasi dalam proses peningkatan kualitas, maka aspek baru pengetahuan, sikap dan keterampilan mengoperasikan teknologilah yang akan menyebabkan perubahan kepemimpinan dan anggota organisasi. Jika muncul dari perubahan motivasi karyawan dalam organisasi kelompok kerja, maka perubahan nyata yang terjadi adalah perubahan manajemen kualitas sumber daya manusia. Ini semua adalah reaksi positif terhadap perubahan.

Agar program perubahan berhasil, orang membutuhkan motivasi dan kemampuan untuk mengubah perilaku mereka. Hal ini tergantung atas faktor apa yang mempengaruhi perilaku dan faktor apa yang mengubah seseorang. Faktor internal yang dapat mempengaruhi perilaku meliputi pengetahuan organisasi, keterampilan, keyakinan, lingkungan dan visi. Faktor variabel, di sisi lain, adalah kemampuan untuk menghasilkan keuntungan nyata atau menghindari kerugian pribadi. Berbagai faktor yang mempengaruhi perubahan perilaku adalah:

\section{a. Pengetahuan}

Pengetahuan adalah dorongan dasar untuk transformasi perilaku semua anggota organisasi. Semakin banyak informasi yang di berikan kepada anggota organisasi, semakin mudah untuk memenuhi kewajiban yang berubah. Oleh karena itu, pengetahuan secara strategis diprioritaskan sebagai salah satu persyaratan utama untuk meningkatkan perilaku anggota suatu organisasi. Orangorang dalam organisasi yang menggunakan pengetahuan minimal selalu tertinggal dari mereka yang menambahkan pengetahuan baru.

\section{b. Keterampilan}

Keterampilan fisik dan non fisik adalah kemampuan seseorang dalam melakukan suatu pekerjaan baru. Pekerjaan fisik membutuhkan keterampilan fisik. Untuk mempersiapkan sesuatu, membutuhkan keterampilan non-fisik. Oleh karena itu, ada hubungan antara keterampilan dan proses komunikasi interpersonal. Keterampilan lebih sulit untuk diubah dan dikembangkan daripada pengetahuan. Perubahan teknologi erat kaitannya dengan pola perilaku naluriah. Proses perubahan reaksi naluriah anggota organisasi berlangsung dalam waktu yang relatif lama karena tidak mudah mengubah unsur-unsur kebiasaan, terutama budaya.

\section{c. Kepercayaan}

Keyakinan anggota organisasi menentukan sikap mereka untuk melakukan sesuatu dengan menggunakan pengetahuan dan keterampilan mereka. Pengetahuan dan keterampilan baru dapat tersedia bagi anggota organisasi dalam beberapa cara. Tapi dia dipengaruhi oleh keyakinannya akan kegunaan pengetahuan dan keterampilan yang diperolehnya. Dengan kata lain, relatif sulit untuk mengubah keyakinan. Oleh karena itu, untuk mendidik anggota suatu organisasi, pertama-tama perlu diketahui keyakinan yang dimiliki anggota organisasi tentang aspekaspek yang dirasakan dari manfaat pelatihan.

\section{d. Lingkungan}

Lingkungan organisasi mempengaruhi perilaku anggota organisasi melalui penghargaan atas perilaku yang diinginkan. Lingkungan organisasi dan masa depannya yang cerah, seperti pemimpin teladan dan panutan, mempengaruhi kecepatan dan kualitas perubahan perilaku di antara anggota organisasi. Apa yang ditawarkan organisasi kepada anggotanya dan apa yang diterima organisasi. Keberhasilan suatu organisasi 
sangat tergantung pada apa yang dapat ditawarkan kepada anggotanya. Semakin tinggi tingkat insentif yang diberikan, semakin efektif dalam mengubah perilaku anggota organisasi. Sebaliknya, organisasi yang tidak efisien atau gagal cenderung menghasilkan perubahan perilaku yang tidak efektif.

Tujuan suatu organisasi ditentukan oleh keyakinan umum para pemimpin organisasi yang menciptakan lingkungan tertentu. Tujuan mengalir dari visi organisasi dan nilai masa depan. Pemimpin organisasi dengan visi dan tujuan yang jelas menciptakan lingkungan yang mendorong tindakan yang efektif. Di satu sisi, ini hanya menciptakan kebingungan di antara anggota organisasi.

Seiring bertambahnya pengetahuan yang ada, anggota organisasi semakin mengetahui dan memahami apa yang mereka butuhkan untuk melakukan pekerjaan mereka. Anggota organisasi membutuhkan keterampilan dalam bentuk kapasitas fisik dan tidak berwujud untuk melakukan tugas-tugas baru. Kepercayaan menentukan apakah anggota organisasi benar-benar menggunakan teknologi dan keterampilan baru.

Lingkungan organisasi membentuk tujuan organisasi yang membentuk standar yang dapat diterima. Tujuan organisasi itu sendiri ditentukan oleh visi organisasi dan dapat menciptakan lingkungan baru. Ini juga dapat menjadi faktor dalam meningkatkan kecerdasan emosional dan mental para anggotanya, yang akan membantu organisasi mengelola perubahan dengan lebih baik.

Pengembangan organisasi yang efektif memiliki ciri-ciri sebagai berikut.:

1) Strategi terencana untuk mendiagnosis masalah yang dihadapi organisasi secara akurat dan akurat dan mencapai perubahan organisasi dengan tujuan yang jelas.

2) Kerjasama antara berbagai pihak yang terkena dampak perubahan organisasi.

3) Fokus atas cara-cara baru yang diperlukan untuk meningkatkan hasil seluruh organisasi dan semua unit kerjanya.

4) Mengandung nilai-nilai kemanusiaan dimana pengembangan potensi manusia merupakan bagian terpenting.

5) Menggunakan pendekatan yang dijanjikan untuk selalu mempertimbangkan pentingnya hubungan antar organisasi, interaktif dan saling ketergantungan antara satu organisasi dengan organisasi lainnya.
6) nit-unit kerja yang beragam seperti bagianbagian dalam suasana yang bersatu.

7) Gunakan metode ilmiah untuk meningkatkan efisiensi organisasi.

\section{e. Perilaku Pelaku Perubahan}

Ada tiga perubahan perilaku yang dapat berpengaruh dalam proses perubahan, yaitu:

a. Para pelaku perubahan dengan otoritas formal (legitimacy of change) adalah mereka yang sadar akan otoritas yang sah.

b. Para pendorong dan penganjur timbulnya perubahan (instigators of change) adalah Orang-orang yang merasa perlu berubah karena telah membandingkan hal-hal baik dengan tempat lain, seperti mereka yang kembali lebih awal dalam studi banding.

c. Para fasilitator perubahan (facilitator of change) adalah sebuah otoritas diakui dan dikenal sebagai pemimpin informal yang memfasilitasi dan mempromosikan proses perubahan.

Para pelaku perubahan di atas memiliki karakteristik dan atribut sebagai berikut:

a. Lebih memiliki ide, gagasan, semangat, dan keberanian yang inovatif.

b. Selalu waspada terhadap hal-hal baru yang berbahaya dengan memperhatikan resiko yang rendah.

c. Memiliki keinginan agar organisasi, komunitas, atau institusi berkembang dan memiliki loyalitas tinggi dan kemauan yang kuat.

d. Cerdas dalam berorganisasi dan cerdas dalam politik, memahami sistem kekuasaan dan batas-batas perubahan yang dibawa dan diubahnya, namun tidak dapat dibatasi oleh hambatan dan keterbatasan yang ada.

e. Dapat menjadi anggota dan pemain tim yang efektif serta gampang dan senang berkawan.

f. Merasa aman

g. Faktor-faktor yang berkaitan dengan ekonomi

h. Takut pada hal yang tidak diketahui

i. Pengakuan

Sementara penolakan secara organisasional disebabkan oleh:

1. Inersia struktual atau penolakan terstruktural 
2. Fokus pada perubahan yang berdampak luas

3. Inersia pada kelompok kerja

4. Ancaman terhadap keahlian dan kemampuan

5. Ancaman terhadap kekuasaan yang telah mapan dan merdeka

6. Ancaman terhadap alokasi sumber daya yang dimiliki.

Taktik Dalam Mengatasi Penolakan atas Perubahan

Bersumber pada pernyataan Coch dan French Jr. (1948) yang mengungkapkan ada enam hal yang bisa dipakai untuk mengatasi resistensi perubahan yaitu:

1. Pendidikan dan komunikasi. Berikan semua pemangku kepentingan deskripsi rinci tentang tujuan kontekstual dan hasil penerapan perubahan, berkomunikasi dengan berbagai cara. Konferensi, diskusi, laporan, presentasi, dan format lainnya..

2. Partisipan. Mengjak semua pihak untuk mengambil keputusan. Kepala adalah penyelenggara dan layak berperan sebagai anggota perempuan dari Departemen Sinkronisasi. Anggota organisasi dapat membuat keputusan.

3. Memberikan kelonggaran serta dukungan. Jika anggota team takut atau cemas, lakukan konsultasi atau bahkan terapi dan memberikan materi-materi. Memang memakan waktu, namun akan mengurangi tingkat penolakan.

4. Negosiasi. Cara lain untuk melakukan ini adalah bernegosiasi dengan pihak yang menentang perubahan. Cara ini bisa digunakan ketika lawan memiliki kekuatan yang kecil.

5. Manipulasi dan Kooptasi. Manipulasi adalah menutupi kondisi yang sesungguhnya dengan menciptakan kondisi yang baru. Kooptasi dilakukan dengan cara memberikan posisi kepada pimpinan penentang perubahan dalam pngambilan keputusan.

6. Paksaan. Taktik terakhir sangat penting. Ini mengancam dan menjatuhkan sanksi kepada mereka yang menentang perubahan tersebut.

\section{Kesimpulan}

Dalam kehidupan perubahan tidak bisa dihindari. banyak upaya dan pendekatan yang sudah dilakukan oleh berbagai pihak guna memecahkan duduk perkara yang timbul dari dampak adanya perubahan. Perubahan memang akan terjadi secara terus-menerus, baik lantaran disebabkan oleh faktor eksternal maupun faktor internal. Oleh karenanya, maka diperlukan kepekaan dan kemampuan organisasi atau manajemen terhadap perubahan. Jika ingin menghadapi dan mampu mengatasi suatu perubahan, kita perlu melakukan manajemen perubahan yang berarti adanya upaya yg diterapkan untuk mengelola sebab akibat yang ditimbulkan karena terjadinya perubahan dalam organisasi.

Pada dasarnya, tidak semua orang senang atau siap terhadap sebuah perubahan di dalam organisasi, namun demikian perubahan trsebut mau tidak mau wajib dihadapi. Lantaran memang intinya diharapkan manajemen perubahan agar menunjuk kepada hal yg positif bagi organisasi.

\section{Daftar Pustaka}

Alamsyah, Kamal. 2004. Perilaku Organisasi dalam Birokrasi Pemerintahan. Yogyakarta: Pustaka Raja.

Arsyad, Azhar. 2003. Pokok Pokok Manajemen. Yogyakarta: Pustaka Pelajar

Bangun, W., 2012. Manajemen sumber daya manusia

Ganyang, M.T., 2018. Manajemen Sumber Daya Manusia Konsep dan Realita

J. Winardi, Prof, Dr, SE. 2005. Manajemen Perubahan. Jakarta: Kencana.

L. Coch dan J.R.P.French, Jr. 1948."Overcoming Resistance to Change"

Mangkunegara, A.A.P., 2016. Manajemen sumber daya manusia perusahaan. PT. Remaja Rosdakarya

Siagian, Sondang P. 2003. Filsafat Administrasi. Jakarta: Bumi Aksara.

Siagian, Sondang P. $1997 . \quad$ Organisasi Kepemimpinan dan Perilaku Administrasi. Jakarta: PT Toko Gunung Agung

Suganda, Dann. 1986. Manajemen Administrasi. Bandung: Sinar Baru.

Sikula, A.E., 2000. Manajemen sumber daya manusia. Erlangga: Bandung.

Stoner, A.F., 2006. Manajemen Sumber Daya Manusia. Jakarta: Bumi Aksara. 
Stephan, P. and Coulter, M., 2009. Manajemen Sumber Daya Manusia. Jilid Satu. Edisi.

Utomo, Warsito. 2007. Administrasi Publik Baru Indonesia. Jakarta: Pustaka Pelajar.

Wicaksono, Kristian Widya. 2006. Administrasi dan Birokrasi Pemerintah. Graha Ilmu. Yogyakarta. 